\title{
PERSEPSI PERAWAT TENTANG PERAN DAN FUNGSI MAHASISWA PRAKTIK DI RSJD Dr.AMINO GONDOHUTOMO SEMARANG
}

\section{PERCEPTION OF NURSE ABOUT ROLE AND FUNCTION STUDENT PRACTICE in RSJD Dr. AMINO GONDOHUTOMO SEMARANG}

\author{
Hani Tuasikal ${ }^{1}$, Selpina Embuai ${ }^{2}$, Moomina Siauta ${ }^{3}$ \\ ${ }^{1}$ Akper RumkitTk II dr. J. A. Latumeten \\ ${ }^{2,3}$ Program StudiI lmu Keperawatan Universitas Kristen Indonesia Maluku \\ Email: hanituasikal@gmail.com
}

\begin{abstract}
Perception Of Nurse About Role And Function Student Practice In Rsjd Dr. Amino Gondohutomo Semarang. Students practice is individual that apply theory owned in hospital and the hope of students going to grow self-trust to be an individual nurse adult. students expectations were not fulfilled because of a routine students every day and not based on the role and function student in hospital of causing assumption that student practices can only assists a nurse in compliance with instructed. The purpose study to know perception nurse about the role and functions students practice in hospital. Qualitative research with a phenomenological approach. Samples carried out with a purposive method, consists of 4 participants. Data collection techniques with in-depth interviews. Result showed that the perception perception of the role of student nurses practice the role of students as eduktor, caregiver, collaborators and counselors like help change behavior, conducting studies to determine the nursing diagnosis, helps doing therapy for the patient, the patient's everyday needs, discuss the next form of service for patient and perform interaction with patients. The role and the functions of students practice not maximally at the hospital. Suggestions for student practice is more active when asked in hospital. Suggestions for hospital can do the evaluation of the students practice for counselors/CI at the end of stase practic.
\end{abstract}

Keywords: role and function, nursing student

\begin{abstract}
Abstrak : Persepsi Perawat Tentang Peran Dan Fungsi Mahasiswa Praktik Di Rsjd Dr.Amino Gondohutomo Semarang. Mahasiswa praktek merupakan individu yang mengaplikasikan teori yang dimiliki di RS dengan harapan mahasiswa akan menumbuhkan kepercayaan diri untuk menjadi seorang individu perawat dewasa. Harapan mahasiswa tersebut belum terpenuhi karena adanya rutinitas yang dilakukan mahasiswa setiap harinyadan tidak sesuai dengan peran dan fungsi mahasiswa di RS sehingga menimbulkan anggapan bahwa mahasiswa praktik hanya dapat membantu perawat sesuai dengan yang diinstruksikan. Penelitian ini bertujuan untuk mengetahui persepsi perawat tentang peran dan fungsi mahasiswa praktek di RSJD Dr. Amino Gondohutomo Semarang. Penelitian kualitatif dengan pendekatan fenomenologis. Sampel dilakukan secara purposif, berjumlah 4 partisipan. Teknik pengambilan data dengan wawancara mendalam. Hasil penelitian didapatkan bahwa persepsi perawat tentang peran mahasiswa praktek yaitu peran mahasiswa sebagai eduktor, caregiver, kolaborator dan konselor seperti membantu merubah perilaku, melakukan pengkajian menentukan diagnosa keperawatan, membantu melakukan terapi untuk pasien, memenuhi kebutuhan sehari-hari pasien, mendiskusikan bentuk pelayanan selanjutnya untuk pasien dan melakukan interaksi dengan pasien. Peran dan fungsi mahasiswa praktek tidak maksimal di RS. Saran dari peneliti bagi mahasiswa praktek adalah lebih aktif bertanya ketika di RS. Bagi RS dapat melakukan evaluasi dari mahasiswa praktek untuk pembimbing/CI pada akhir stase praktek.
\end{abstract}

Kata kunci: peran dan fungsi, mahasiswakeperawatan

\section{PENDAHULUAN}

Tenaga perawat merupakan "The carring profession" yang mempunyai kedudukan penting dalam menghasilkan kualitas pelayanan kesehatan di rumah sakit dan memiliki kelebihan tersendiri dibandingkan dengan pelayanan kesehatan lainnya (Departemen Kesehatan RI, 2001)

Peran dan fungsi perawat dalam proses pembelajaransangat diperlukan peserta didik karena dapat membimbing untuk mencapai tujuan yang ditetapkan dalam pembelajaran klinik melalui proses peningkatan kemampuan 
intelektual, teknikal dan interpersonal. Perawat yang bekerja pada institusi kesehatan khususnya rumah sakit pendidikan diharapkan mempunyai kualifikasi pendidikan dan sikap positif serta bersedia berperan dalam mengelola pengalaman belajar klinik yang diperlukan peserta didik (Departemen Kesehatan RI, 2001)

Peran mahasiswa di rumah sakit adalah menjadi bagian dari rumah sakit serta menjaga nama baik rumah sakit dan institusi pendidikan dimana mahasiswa tersebut berasal. Peran tersebut menjadi landasan mahasiswa untuk belajar menjalankan fungsinya di rumah sakit untuk belajar secara nyata dalam praktik sehingga kelak menjadi perawat profesional dalam rangka melaksanakan asuhan keperawatan dengan benar, menerapkan pendekatan proses keperawatan, menampilkan sikap/tingkah laku dan menerapkan keterampilan professional (Haryatiningsih Purwandri \& Wastu Adi Mulyono, 2011).

Hasil penelitian Haryatiningsih \& Wastu (2011) terdapat tiga masalah utama yang dihadapi mahasiswa ketika praktik klinik, yaitu lingkungan belajar klinik, ketidaksesuaian penerapan teori dalam praktik sehingga perawat rumah sakit perlu pelatihan pembentukan lingkungan belajar klinik untuk seluruh staf perawat. Kemampuan perawat klinis dalam menyampaikan pengetahuan kepada mahasiswa merupakan dimensi efektifitas pengajaran yang penting. ${ }^{5}$ Proses pengajaran klinik yang dikatakan berhasil, yaitu perawat dapat membimbing mahasiswa dengan baik, terjalinnya komunikasi dan adanya persepsi yang baik dari perawat klinis terhadap mahasiswa itu sendiri (Haryatiningsih Purwandri \& Wastu Adi Mulyono, 2011).

Persepsi merupakan salah satu prosses psikologis yang mendasar dan memiliki pengaruh yang besar terhadap proses terbentuknya ingatan, pikiran dan proses belajar. Persepsi timbul dari setiap individu dan dipengaruhi oleh keadaan lingkungan sekitar serta diri individu yang bersangkutan. Perawat sebagai seorang individu dalam menghasilkan suatu persepsi tentang proses pembelajaran klinik harus memiliki pemahaman dasar tentang prinsip, praktik, proses pengajaran dan pembelajaran untuk menjalankan tanggung jawab professional yang efektif dan efisien. Persepsi perawat klinis yang berbedabeda terhadap mahasiswa praktik disebabkan oleh external perceptions atau self perceptions.External perceptions dan self perceptions dipengaruhi oleh beberapa faktor yaitu sikap, pengalaman, motif, ketertarikan dan harapan. Seluruh faktor tersebut akan menghasilkan persepsi yang berbeda-beda terhadap mahasiswa praktik, ada yang berupa persepsi positif maupun negatif (Kunanto, 2004).

Persepsi perawat terhadap mahasiswa praktik ada yang positif dan negatif. Persepsi positif berasal dari dirinya sendiri terhadap mahasiswa praktik tentang salah satu tanggung jawab perawat yang disesuaikan dengan perannya sebagai pendidik (edukator). Perawat sebagai educator berperan dalam membimbing, membina dan memberi contoh yang baik kepada mahasiswa praktik (Bastable Susan, 2002). Persepsi seperti diatas, masih sedikit yang terpikirkan oleh perawat klinis karena banyaknya pekerjaan dan tanggung jawab yang dibebankan kepada perawat dalam merawat pasien dan membimbing mahasiswa.

Hasil wawancara dengan 5 perawat di RSJD Dr Amino Gondhoutomo mendapatkan hasil bahwa 2 perawat mengatakan bahwa fungsi dan peran mahasiswa di rumah sakit sebagai membantu perawat dalam membantu tugas-tugas perawat, melakukan pemeriksaan kepada pasien dan mengontrol kegiatan pasien diruangan. 2 perawat lainnya mengatakan bahwa mahasiswa sangat dibutuhkan karena sesuai fungsi mahasiswa itu sendiri di rumah sakit sebagai pembantu perawat dalam melakukan asuhan keperawatan kepada pasien. 1 perawat mengatakan bahwa fungsi mahasiswa membantu perawat di rumah sakit sedangkan perannya mahasiswa melakukan asuhan keperawatan kepada pasien.

Mahasiswa di rumah sakit tidak sesuai dengan peran dan fungsinya karena mahasiswa lebih banyak diperintahkan untuk melakukan rutinitas seperti merapikan tempat tidur pasien, mengantarkan pasien ke ruang electro convulsive therapy (ECT) hingga waktu yang lama,mengukur tekanan darah pasien, memberikan obat kepada pasien dan lain-lain. Mengantarkan pasien ke ruang ECT memang termasuk salah satu proses pembelajaran yang didapatkan oleh mahasiswa tetapi pada praktiknya tindakan ini dilakukan berlebihan sehingga tidak efektif dan berdampak pada kemampuan mahasiswa untuk memahami tindakan keperawatan yang lainnya. Rutinitas seperti diatas membuat mahasiwa tidak berkembang dalam melakukan tindakan keperawatan karena hanya berpatokan pada rutinitas yang dilakukan tanpa memperhatikan pada apa yang diharapkan oleh mahasiswa tersebut. Harapan mahasiswa berdasarkan peran dan fungsinya di rumah sakit yaitu untuk dapat belajar mengaplikasikan teori atau ilmu yang mereka dapat di bangku kuliah sehingga dapat berkembang serta menumbuhkan kepercayaan 
diri untuk menjadi seorang individu perawat dewasa. Harapan mahasiswa tersebut belum terpenuhi karena adanya rutinitas yang dilakukan mahasiswa setiap harinya.

Persepsi perawat yang tidak sesuai dengan peran dan fungsi mahasiswa di rumah sakit menimbulkan anggapan bahwa mahasiswa praktik hanya dapat membantu perawat sesuai dengan yang diinstruksikan, melakukan rutinitas setiap harinya, padahal mahasiswa mengharapkan bimbingan untuk melaksanakan proses asuhan keperawatan secara profesional tanpa harus melakukan rutinitas berlebihan yang dapat menyita waktu mahasiswa untuk belajar lebih banyak di rumah sakit seperti menambah pengalaman dan mengaplikasikan teori yang tidak dapat dilakukan di bangku kuliah. Penelitian ini bertujuan untuk mengetahui persepsi perawat tentang peran dan fungsi mahasiswa praktek di RSJD Dr. Amino Gondohutomo Semarang

\section{METODE}

Penelitian ini menggunakan metode kualitatif dengan pendekatan fenomenologi. Partisipan dipilih dengan metode purposif sejumlah 4 orang perawat di ruang rawat inap RSJD Dr Amino Gondohutomo Semarang. Sebagai pertimbangan etik partisipan secara sukarela telah menandatangani Informed Consent (self determination), dijaga kerahasiaan identitasnya selama dan sesudah penelitian (privacy), semua partisipan diperlakukan sama dengan mengganti nama partisipan dengan kode atau nomor (anonymity), partisipan memiliki hak untuk menarik diri apabila tidak bersedia (right to withdraw), serta dijaga kerahasiaan informasinya (confidentiality). Selama pengambilan data peneliti telah berusaha untuk memberi kenyamanan pada partisipan dengan mencari tempat/ruang yang nyaman selama memberi informasi (Miles \& Hubreman, 1994)

Pengumpulan data dilakukan dengan cara wawancara mendalam dengan mengkaji informasi dari partisipan. Untuk meningkatkan ketepatan pengumpulan data dan menjamin pencapaian hasil yang komprehensif tentang persepsi dari partisipan, peneliti menggunakan perpanjangan pengamatan untuk menanyakan informasi-informasi baru yang tidak ditanyakan pada saat wawancara mendalam. Untuk menjaga konsistensi jawaban dari partisipan peneliti menggunakan triangulasi waktu.

Rancangan wawancara yang dibuat peneliti berguna untuk mendapatkan data berbagai perasaan dan pikiran partisipan yang berkaitan denganpersepsi perawat tentang peran dan fungsi mahasiswa parktik. Partisipan di wawancarai setelah mendapatkan ijin dari partisipan itu sendiri. Hasil wawancara yang didapatkan dipahami kemudian dituangkan dalam bentuk transkip wawancara yang akan digunakan dalam analisis data.

\section{HASIL}

Partisipan dalam penelitian ini berjumlah 4 orang adalah perawat yang belum pernah menjadi CI/Kepala ruangan di RSJD Dr Amino Gondohutomo Semarang. Partisipan pertama (P1) bekerja di RS selama 20 tahun, partisipan kedua (P2) dan ketiga (P3) selama 2 tahun dan partisipan keempat (P4) selama 3 tahun.

Peneliti telah mengidentifikasi 3 tema yang terbentuk dari 8 sub tema dan 12 kategori. 3 tema tersebut yaitu: 1) Persepsi perawat tentang peran mahasiswa praktik; 2) Persepsi perawat tentang peran mahasiswa praktik; 3) Peran dan fungsi mahasiswa praktik tidak maksimal di RS.

\section{Tema 1: Persepsi perawat tentang peran mahasiswa praktik}

Dua dari empat partisipan menyatakan pendapat tentang peran mahasiswa praktik sebagai edukator dalam membantu merubah perilaku klien adalah mahasiswa membantu dalam pelaksanaan TAK dan mengawasi pasien, seperti pernyataan dari salah satu partisipan dibawah ini:

“..Terbantu dalam hal pengawasan pasien, dalam pelaksanaan TAK......”(P1)

Dua dari empat partisipan menyatakan bahwa peran mahasiswa praktik sebagai caregiver dalam melakukan pengkajian adalah dapat menceritakan kondisi pasien dan mahasiswa harus mengetahui kondisi pasien PK (perilaku kekerasan) seperti ini, halusinasi seperti ini, seperti pernyataan dibawah ini:

“...Jadi kalau misalkan sudah anu kan tahu kondisi pasiennya. Misalnya pasien si A itu untuk mahasiswa bisa cerita pasiennya ngapain aja, komunikasinya gimana gitu, jadi mahasiswa sudah bisa menceritakan sesuai kondisi pasien masing-masing...”(P2)

Partisipan menyatakan bahwa menyatakan peran mahasiswa sebagai kolaborator dalam membantu melakukan terapi untuk pasien adalah pelaksanaan TAK, mengantarkan pasien ke EKG, ECT, nyuntik dan REHAB, seperti pernyataan dari partisipan dibawah ini: 
“...Kalau disuruh menolak jarang, yang disuruh yah tetap ikut, misalnya disuruh ECT itu misalkan yah berangkat, yah maulah. Selama ini kalau saya perintah, kalau nggak yah saya marahi..."(P1)

\section{Tema 2: Persepsi perawat tentang peran mahasiswa praktik}

Dua pasrtisipan menyatakan bahwa fungsi mahasiswa sebagai independen dalam hambatan melaksanakan asuhan keperawatan adalah seharusnya bisa melaksanakan ASKEP, memenuhi standar kedatangan dan belum maksimal dalam pemberian ASKEP, seperti berikut:

“..Terkait peran dan fungsi, seharusnya mahasiswa itu bisa melaksanakan asuhan keperawatan juga..”(P3)

Dua partisipan menyatakan bahwa fungsi mahasiswa sebagai interdependen dalam hambatan dalam bekerjasama dengan perawat dalam pemberian asuhan keperawatan adalah kurang kooperatif terhadap aktifitas keperawatan diam melihat aktifitas perawat di ruangan, seperti pernyataan dari salah satu partisipan dibawah ini:

"Kan sudah 1 minggu seharusnya mereka kan tau kalau jam makan pagi itu seharusnya, tapi merekanya malah diam aja tahu perawatnya bagi sendirian pasiennya banyak tapi kok mereka cuma berdiri cuman sebagai itu aja sih..”(P4)

Dua partisipan menyatakan bahwa fungsi mahasiswa sebagai dependen kurang maksimal melaksanakan tugas dari perawat adalah hanya mengikuti kegiatan di ruangan, mahasiswa tidak tahu cara menyuntik seperti IM dan harus bisa mengumpulkan diagnosa keperawatan, seperti pernyataan dibawah ini:

“.. Harus bisa mengumpulkan diagnosa keperawatan yang bisa diangkat terus kemudian membuat perencanaan dan mengimplementasikan dan mengevaluasikannya.."(P2)

\section{Tema 3: Peran dan fungsi mahasiswa praktik tidak maksimal di RS}

Seluruh partisipan menyatakan bahwa evaluasi untuk peran dan fungsi mahasiswa praktik adalah mahasiswa belum, mungkin, cukup, menjalankan peran dan fungsinya dan ada sebagian menjalankan peran dan fungsinya dengan baik, seperti pernyataan dari salah satu partisipan dibawah ini:
“...Cukup sesuai soalnya kalau sesuai kalau memang bener-bener dalam praktiknya itu dia menerapkan semuanya, nah berarti kalau untuk yang cukup ya sekedar penilaian aja ya sedang sama dengan cukup..”(P2)

Dua partisipan menyatakan bahwa evaluasi untuk peran dan fungsi mahasiswa praktik adalah belum maksimal menjalankan praktiknya dan askepnya, seperti pernyataan dari partisipan dibawah ini:

\section{“..Dia masih kurang kadang-kadang kurang} maksimal dalam pemberian askepnya...”(1)

\section{PEMBAHASAN}

Hasil penelitian tentang persepsi perawat terhadap peran mahasiswa praktik adalah partisipan menyatakan bahwa mahasiswa membantu dalam pelaksanaan TAK dan mengawasi pasien. Pendapat partisipan tersebut sesuai dengan peran perawat sebagai edukator yakni menjelaskan konsep dan fakta kesehatan, mendemonstrasikan prosedur seperti aktivitas perawatan diri dan memperbaiki tingkah laku belajar. Mahasiswa melaksanakan TAK dan mengawasi pasien merupakan salah satu bentuk dalam merubah perilaku klien dalam mengetahui cara menyembuhkan dirinnya sendiri maupun mendisiplikan dirinya sendiri sehingga memprmudah dalam proses penyembuhan klien (Gruendemann Barbara J, 2005)

Peran perawat tidak hanya sebagai edukator akan tetapi sebagai caregiver. Partisipan menyatakan bahwa dalam melakukan pengkajian mahasiswa mampu meneceritakan kondisi pasien mahasiswa harus mengetahui kondisi pasien PK (perilaku kekerasan) seperti ini, halusinasi seperti ini, mahasiswa mengetahui cara untuk menangani pasien dan total melakukan asuhan keperawatan secara komprehensif dalam menentukan diagnosa keperawatan. Mahasiswa mampu menjalankan fungsi perawat sebagai caregiver di RS. Mahasiswa menggunakan nursing process untuk mengidentifikasi diagnosa keperawatan, mulai dari masalah fisik-psikologis (Bastable, Susan B, 2002).

Peran perawat sebagai kolaborator yang disampaikan oleh partisipan bahwa mahasiswa dalam membantu melakukan terapi untuk pasien adalah pelaksanaan TAK, nyuntik, mengantarkan pasien ke EKG, ECT dan REHAB. Memenuhi kebutuhan sehari-hari pasien adalah menyuapi pasien PK (perilaku kekerasan) dan mandiin pasien. bahwa dalam mendiskusikan bentuk 
pelayanan selanjutnya untuk pasien adalah bertukar informasi dengan perawat. Kolaborasi dengan pemberi perawatan kesehatan lainnya mengembangkan suatu hubungan interdependen dan nantinya akan berdampak pada mahasiswa itu sendiri dalam menjalankan kerja sama baik dengan sesama tenaga kesehatan maupun tenaga kesehatan lainnya (Gruendemann Barbara J, 2005).

Peran perawat sebagai konselor dari pernyataan partisipan adalah melakukan interaksi dengan klien seperti ada yang mengajak komunikasi dengan pasien dan komunikasi terapetik. Komunikasi yang masih kaku dan kounikasi yang kurang mengena. Melakukan interaksi dengan klien dan hambatan menyampaikan informasi kepada pasien merupakan dua hal yang saling ketergantungan, misalnya sudah melaksanakan interaksi dengan klien akan tetapi apabila masih kaku dalam interkasi akan menjadi hambatan dalam berinterkasi dengan pasien (Bastable, Susan B, 2002).

Hasil penelitian persepsi perawat tentang fungsi mahasiswa praktik. Fungsi mahasiswa praktik sebagai independen yang didapatkan dari partisipan bahwa hambatan dalam melaksanakan asuhan keperawatan adalah seharusnya bisa melaksanakan ASKEP, memenuhi standar kedatangan dan belum maksimal dalam pemberian ASKEP. Mahasiswa mampu menjalankan fungsi perawat sebagai independen secara mandiri dengan melakukan pengkajian hingga menentukan diagnosa yang tepat untuk klien (Christensen, Paula J, 2009).

Fungsi mahasiswa praktik tidak hanya sebagai independen akan tetapi sebagai interdependen. Partisipan menyatakan bahwa fungsi mahasiswa sebagai interdependen adalah dalam hambatan dalam bekerjasama dengan perawat dalam pemberian asuhan keperawatan adalah kurang kooperatif terhadap aktifitas keperawatan diam melihat aktifitas perawat di ruangan, mahasiswa tidak disiplin dalam mematuhi jam masuk praktik dan inisiatif untuk melakukan pekerjaan di ruangan masih kurang. Hambatan dalam bekerjasama dengan perawat dalam pemberian asuhan keperawatan adalah kurang kooperatifnya mahasiswa terhadap aktivitas di ruangan (Potter \& Perri, 2005).

Fungsi mahasiswa yang terakhir yakni sebagai dependen. Partisipan menyatakan bahwa mahasiswa kurang maksimal melaksanakan tugas dari perawat adalah hanya mengikuti kegiatan di ruangan, mahasiswa tidak tahu cara menyuntik seperti IM dan harus bisa mengumpulkan diagnosa keperawatan. Kurangnya keaktifan mahasiswa praktik diakibatkan karena perawat beranggapan mahasiswa praktik tidak tahu tentang cara menyuntik dan penurunan dalam skill dan kemampuannya (Christensen, Paula J, 2009).

Peran dan fungsi mahasiswa praktik tidak maksimal di RS didapatkan dari hasil evalusi dari partisipan untuk mahasiswa praktik. Partisipan menyatakan bahwa mahasiswa mahasiswa belum, mungkin, cukup, menjalankan peran dan fungsinya dan ada sebagian menjalankan peran, fungsinya dengan baik, latihan tanggung jawab dan mahasiswa yang terlambat pulangnya lebih lama.

Teori yang didapatkan dari pernyataan partisipan bahwa mahasiswa sebagian belum menjalankan peran dan fungsinya dengan baik di rumah sakit karena mahasiswa hanya sekedar untuk mendapatkan nilai, hanya menjalankan proses selama di rumah sakit tanpa menyerap ilmu yang didapatkan di RS, seharusnya mahasiswa di RS melaksanakan praktik keperawatan dan proses keperawatan secara nyata sesuai kemampuannya serta dibantu oleh pembimbing klinis sehingga mampu menjadi perawat yang profesional (Simamora, Roymond H, 2009).

\section{SIMPULAN}

Peran mahasiswa praktik terkait dengan peran mahasiswa sebagai edukator, caregiver, kolaborator dan konselor adalah membantu merubah perilaku klien, melakukan pengkajian, menentukan diagnosa keperawatan, membantu melakukan terapi untuk pasien, memenuhi kebutuhan sehari-hari pasien, mendiskusikan pelayanan selanjutnya dengan perawat, melakukan interaksi dengan pasien dan hambatan dalam berinteraksi dengan pasien. Fungsi mahasiswa praktik di RS sebagai independen, interdependen dan dependen adalah hambatan dalam melaksanakan asuhan keperawatan, hambatan dalam bekerjasama dengan untuk memberikan asuhan keperawatan dan kurang maksimal mekalsanakan tugas dari perawat. Peran dan fungsi mahasiswa tidak dijalankan secara maksimal di rumah sakit dipengaruhi oleh perilaku dan proses belajar mahasiswa yang kurang maksimal. Beberapa mahasiswa yang mengalami penurunan skil dan kemampuan. Perawat di ruangan juga dapat ikut serta membimbing mahasiswa tidak hanya pembimbing/CI karena salah satu peran perawat yaitu edukator baik dalam memberikan ilmu yang dimiliki kepada pasien maupun kepada mahasiswa. 


\section{SARAN}

Saran bagi mahasiswa paraktik harus berperilaku yang baik seperti aktif bertanya, kreatif, inisiatif untuk melakukan aktivitas keperawatan tanpa diperintahkan terlebih dahulu oleh perawat. Bagi perawat melakukan diskusi 2 hari sekali untuk berbagi informasi-informasi yang baru tentang peroses asuhan keperawatan sehingga meningkatkan pengetahuan baik dari perawat maupun mahasiswa praktik. Bagi rumah sakit adanya fasilitator atau mentor untuk meningkatkan skil dan kemampuan mahasiswa praktik di ruangan. Peneliti selanjutnya juga dapat menggunakan berbagai teknik pengambilan data ataupun tempat yang lebih luas seperti seluruh rumah sakit sehingga dapat memberikan hasil yang lebih bervariasi.

\section{DAFTAR PUSTAKA}

Bastable, Susan B. (2002) Perawat Sebagai Pendidik: Prinsip-prinsip Pengajaran dan Pembelajaran. Jakarta: EGC.
Christensen, Paula J. (2009) Proses Keperawatan :Aplikasi Model Konseptual. Ed,4. Jakarta: EGC.

Departemen Kesehatan RI.(2001)Konsep dan Mutu Manajemen Rumah Sakit.Jakarta.

Gruendemann, Barbara J. (2005) Buku Ajar Keperawatan Peroperatif. Vol,1. Jakarta: EGC.

Purwandari Haryatiningsih \& Wastu Adi M. (2011) Permasalahan Mahasiswa Pada Penempatan Praktik Ners Pertama Kali Di Stase Keperawatan Anak. Volume II Nomor 1:41-42. Januari 2011 Jurnal Penelitian Kesehatan Suara Forikes.

Kusnanto. (2004) Pengantar Profesi dan Praktik Keperawatan Profesional. Jakarta : EGC.

Miles \& Hubreman. (1994) Qualitative Data Analysis Second Edition. United States Of Amerika: Sage Pubilcation Ltd.

Potter \& Perry. (2005) Buku Ajar Fundamental Keperawatan: Konsep Proses dan Praktik. Vol,1. Ed,4. Jakarta: EGC.

Simamora, Roymond H. (2009) Buku Ajar Pendidikan dalam Keperawatan. Jakarta: EGC. 